УДК 342.9

T.В. Дракохруст

кандидат наук з державного управління, доцент, доцент кафедри міжнародного права, міжнародних відносин та дипломатії Тернопільського національного еконолічного університету

\title{
ОСОБЛИВОСТІ ПРАВОВОГО ЗАБЕЗПЕЧЕННЯ ДЕРЖАВНОЇ МІГРАЦІЙНОЇ ПОЛІТИКИ УКРАЇНИ
}

Міграційна політика держав не може бути постійною, адже вона може змінюватися та визначатися залежно від багатьох політичних, економічних, соціальних, культурних та інших чинників. Ïї реалізація має бути забезпечена чітким та прозорим регулюванням на державному рівні в частині нормативно-правового, інституціонального, кадрового забезпечення.

Україна пройшла неоднозначний шлях формування міграційної політики, зі своїми проблемами, несподіваними політичними рішеннями та формами їі реалізації. Все це потребує вивчення особливостей правового забезпечення державної міграційної політики України.

Метою статті є детальний аналіз правового забезпечення державної міграційної політики України у контексті поетапного розвитку міграційного законодавства України, який, на нашу думку, має бути спрямований на досягнення трьох головних цілей: 1) управління міграційними процесами (обсягом та спрямованістю міграційних потоків) в Україні, у тому числі регулювання в’їзду та виїзду мігрантів, шляхом здійснення імміграційного контролю; 2) внутрішньої адаптації та інтеграції іммігрантів на території України; 3) моніторинг та попередження виникнення міграційних викликів та загроз у контексті розвитку глобалізаційних процесів у світі.

Дослідження особливостей формування державної міграційної політики України загалом і нормативно-правового забезпечення регулювання міграційних процесів зокрема знайшли своє відображення у працях таких вітчизняних учених, як: Е. Лібанова, О. Малиновська, М. Ніколайчук, С. Пирожков, О. Позняк, О. Хомра та ін.

У формуванні й становленні внутрішнього міграційного законодавства можна умовно визначити чотири етапи: а) до прийняття Конституції; б) після прийняття Конституції, що включає період подальшої розробки, вдосконалення, систематизації та можливої кодифікації міграційного законодавства; в) у період гібридної війни Росії проти України; г) у контексті вступу України до ЄС.

Якщо вести мову про перший період, то однозначно слід звернути увагу на Декларацію про державний суверенітет України від 16 липня 1991 року, де чітко йдеться про принцип державного регулювання міграційних процесів.

Важливими етапами формування міграційного законодавства в «доконституційний» період здійснення міграційної політики України є Закон України «Про громадянство» від 8 жовтня 1991 р., що регулював порядок набуття, визнання та припинення громадянства України на основі принципів інтерпретації громадянства радше як правового, ніж як політичного зв'язку громадян із державою (що узгоджується з концепцією громадянства в міжнародно-правовій практиці), і Закон України «Про національні меншини в Україні» від 25 червня 1992 року [1], у якому зафіксовано основні політичні, економічні та культурні права осіб, що належать до національних меншин, у тому числі їхнє право на вільні контакти зі своєю історичною Батьківщиною.

Закон України «Про громадянство» є спеціальним, адже, крім вищезазначеного, визначено також порядок оскарження рішень з питань громадянства, дій чи бездіяльності органів державної влади, їх посадових і службових осіб.

Цим документом, зокрема, затверджено Положення про Комісію при Президентові України з питань громадянства та Порядок провадження за заявами і поданнями з питань громадянства України та виконання прийнятих рішень. Зазначеним Порядком з-поміж іншого визначено перелік документів, які подаються для встановлення, оформлення та перевірки належності до громадянства України, прийняття до громадянства України, оформлення набуття громадянства України, припинення громадянства України, скасування рішень про оформлення набуття громадянства України, а також процедур подання цих документів та провадження за ними, виконання прийнятих рішень з питань громадянства України [2].

Перша редакція цього Закону була прийнята Верховною Радою України 24 грудня 1993 р. [3] (цей Закон втратив чинність після прийняття Верховною Радою України нової редакції Закону України «Про біженців», про який йтиметься нижче). Хоча на час прийняття цього документа наша держава ще не приєдналася до Конвенції ООН 1951 р. про статус біженців та Протоколу до неї, норми українського закону значною мірою відповідали духу та букві цієї Конвенції та інших міжнародних документів. Передусім, це стосувалося його основоположних статей.

Під час підготовки проєкту нової редакції Закону України «Про біженців» було зроблено спробу врегулювати ті нагальні проблеми, які виникли 
під час застосування закону, прийнятого у 1993 р. Як за обсягом, так і за змістом нова редакція закону є набагато ширшою. Характерною його рисою $€$ те, що відповідно до вимог Конституції України він є законом прямої дії. Тому в ньому знайшли відображення основні питання процедури розгляду клопотань шукачів притулку, прийняття рішень 3 надання, втрати та позбавлення статусу біженця.

Специфічним періодом на шляху формування інститутів українського міграційного законодавства є Закон України «Про правовий статус іноземців» від 4 лютого 1994 року [4] та Правила в'їзду іноземців в Україну, їх виїзду з України і транзитного проїзду через її територію від 29 грудня 1995 року, що регулюють в'їзд до України іноземців та осіб без громадянства.

Уперше в національному законодавстві закріплено право іноземців у встановленому порядку іммігрувати в Україну на постійне проживання або з метою працевлаштування на певний термін, а також тимчасово перебувати на її території.

Засади внутрішньої і зовнішньої української міграційної політики було закладено Конституцією України 1996 року [5], яка: закріплює право на свободу пересування та вільного вибору місця проживання будь-якої особи, що на законних підставах перебуває на території України (ст. 33); визначає правовий статус іноземців, прирівнюючи їх у правах та обов'язках до українських громадян (ст. 26).

Конституція передбачає можливість встановлення обмежень свободи пересування по теритоpiї України та вибору місця проживання для осіб в умовах введення воєнного та надзвичайного стану (ст. 64). Рівною мірою це стосується громадян України, іноземців, осіб без громадянства. Обмеження мають діяти тимчасово, на час введення такого стану, пов'язаного з військовими діями, із стихійними лихами, аваріями чи катастрофою, епідемією, епізоотіями, іншими форс-мажорними обставинами.

Громадяни України, іноземці та особи без громадянства, які на законних підставах перебувають на території України, можуть вільно залишати територію України, а громадяни України - вільно повертатися в Україну. Отже, тут сформульовані права громадян України на вільний в'їзд і виїзд із країни. Щодо в'їзду іноземців у країну, то цитуємо: «на законних підставах перебувають на теритоpiї України». Слід зауважити, що аспект імміграції досить слабо виписаний у Конституції України.

Конституція проголосила, що громадянин України не може бути видворений за межі України, закріпила положення про невидачу громадянина України іншій державі, а також положення про те, що Україна гарантує турботу та захист своїм громадянам, які перебувають за її межами (ст. 25). Без сумніву, у цих положеннях законодавець урахував гіркий історичний досвід вигнання громадян із Радянського Союзу, що було досить поширеним включно до кінця 80-х років минулого століття. Конституція закріпила право кожного звертатися з метою захисту своїх прав до Уповноваженого Верховної Ради з прав людини, а після використання всіх національних засобів правового захисту - до відповідних міжнародних судових установ чи відповідних органів міжнародних організацій, членом чи учасником яких є Україна (ст. 55).

Конституційним визначенням став термін «депортовані народи». Конституцією передбачена розробка та реалізація державних програм повернення депортованих народів (п. 9 ст. 138). Безперечно, це суттєвий крок уперед у юридичному визнанні цієї проблеми як проблеми державної ваги.

Таким чином, у Конституції України знайшли своє відображення різні аспекти міграційних процесів. Закріплені основи регулювання цих процесів, права на свободу пересування та вільний вибір місця проживання. Оскільки норми Конституції $€$ нормами прямої дії, то і звернення до суду для захисту конституційних прав і свобод людини і громадянина безпосередньо на підставі Конституції України гарантується.

Якщо ж говорити про другий період «після прийняття конституції,, то на цьому етапі в структурі міграційного законодавства чіткіше виокремлюються юридичні інститути, у рамках яких конкретизуються зміст та юридичні механізми здійснення відповідних норм:

1) інститут біженців (Доповнення до ст. 75 Кримінального кодексу України, що скасовують кримінальну відповідальність за незаконний перетин кордону України осіб, які прибули в Україну з метою отримання статусу біженців; постанов Кабінету Міністрів України «Про затвердження положення про посвідчення біженця» від 16 лютого 1998 року [6] (Постанова втратила чинність на підставі Постанови КМУ № 185 від 13.03.2013 року і дію Постанови відновлено згідно з Постановою КМУ № 415 від 12.06.2013 року), «Про затвердження порядку надання біженцям грошової допомоги до пенсії від 6 липня 1998 року [7], «Про затвердження Положення про прийом іноземців та осіб без громадянства на навчання до вищих навчальних закладів» від 5 серпня 1998 року та ін.) (втрата чинності від 01.10.2013); 2) інститут трудящих-мігрантів (Наказ Міністерства праці України від 22 травня 1997 року «Про зміни та доповнення до Тимчасового положення про умови і порядок оформлення іноземним громадянам дозволів на працевлаштування в Україні» [8], що розширює коло іноземців, яким не потрібний дозвіл на працевлаштування в Україні; постанов Кабінету Міністрів №№ 79, 1146, 1021 та ін. про порядок надання медичної допомоги іноземним громадянам, які тимчасового перебувають на території України; 3) інститут запобігання нелегальній міграції (Указом Президента України від 
9 січня 1999 року «Про питання імміграційного контролю» координацію діяльності органів виконавчої влади щодо боротьби з незаконною міграцією покладено на Державний комітет у справах охорони державного кордону України, збільшено розміри адміністративних штрафів за сприяння нелегальній міграції; Наказом Державного комітету у справах охорони державного кордону України, Міністерства внутрішніх справ України від 25 грудня 1997 року передбачено затримання та видворення за межі держави порушників законодавства України про державний кордон тощо).

Особливе значення для державного регулювання міграційних процесів має Закон України «Про імміграцію», проєкт якого остаточно був узгоджений між міністерствами і відомствами ще в 1994 році, а ухвалений лише 7 червня 2001 року. [9] Цей Закон визначає умови і порядок імміграції в Україну іноземців та осіб без громадянства, враховуючи досвід, набутий світовим товариством щодо забезпечення прав і свобод людини. Відповідно до Закону іммігрантами визнаються іноземці чи особи без громадянства, які отримали дозвіл на імміграцію і прибули в Україну на постійне проживання, або, перебуваючи в Україні на законних підставах, отримали дозвіл на імміграцію і залишилися в Україні на постійне проживання (ст. 1). Законом визначено засади правового статусу іммігрантів, зазначено, що імміграція в Україну здійснюється у відповідності до квот, які Кабінет Міністрів України буде встановлювати на кожний календарний рік, передбачено умови надання дозволу на імміграцію та видачі посвідки на постійне проживання, порядок подання й оформлення відповідних документів, повноваження державних органів.

3 метою більш ефективної організації виконання Закону України «Про імміграцію» Президент України видав відповідний Указ, яким поклав на Міністерство внутрішніх справ України виконання функцій спеціально уповноваженого центрального органу виконавчої влади з питань імміграції.

Також потрібно зазначити, що на виконання статті 5 Закону України «Про імміграцію» Кабінет Міністрів України 26 грудня 2002 року прийняв Постанову, якою затвердив Порядок формування квоти імміграції, Порядок провадження за заявами про надання послуг на імміграцію і поданнями про його скасування та виконання прийнятих рішень та Порядок оформлення і видачі посвідки на постійне місце проживання [10].

Наступним законом, який можна віднести до другого періоду, є Закон України «Про громадянство України» від 18 січня 2001 р. № 2235-III [11]. Фактично 18 січня 2001 р. Верховна Рада України прийняла нову редакцію Закону України «Про громадянство України», яка замінила Закон України «Про громадянство України» від 8 жовтня 1991 р. Незважаючи на його невеликий обсяг, цей Закон є юридично цілісним, внутрішньо узгодженим та зведеним за змістом, оскільки забезпечує регулювання суспільних відносин у галузі громадянства. До того ж його роль полягає в тому, щоб сформувати стабільність та наявність єдиних правових приписів у сфері реалізації права на громадянство.

Закон України «Про громадянство України» $є$ невеликим за обсягом і до нього неодноразово вносилися зміни. Найсуттєвіші зміни та доповнення були внесені 16 квітня 1997 р. та 18 січня 2001 р.

Цей Закон є спеціальним, адже саме в ньому визначено правовий зміст громадянства України, підстави й порядок його набуття та припинення, повноваження органів державної влади, що беруть участь у вирішенні питань громадянства України, а також порядок оскарження рішень 3 питань громадянства, дій чи бездіяльності органів державної влади, їх посадових і службових осіб.

3 набуттям громадянства України на них поширюється дія Закону України «Про порядок виїзду з України та в'їзду в Україну громадян України». Громадянин України може вільно в'їхати в Україну за національним паспортом.

Одне з головних місць після законів у структурі законодавства про громадянство України посідають укази Президента України. Серед указів Президента України в галузі громадянства суттєве місце посідають укази, спрямовані на забезпечення реалізації положень Закону України «Про громадянство України».

До цієї групи належить Указ Президента України «Питання організації виконання Закону України «Про громадянство України» від 27 березня 2001 р. із змінами і доповненнями, внесеними Указом Президента України від 27 червня 2006 р. Останнім Указом було затверджено нову редакцію Положення про Комісію при Президентові України 3 питань громадянства [12] та Порядок провадження за заявами і поданнями з питань громадянства України та виконання прийнятих рішень [13].

Цей Порядок має велике значення для належної реалізації Закону України «Про громадянство України». У ньому визначено перелік документів, які подаються для встановлення, оформлення та перевірки належності до громадянства України, прийняття до громадянства України, оформлення набуття громадянства України, припинення громадянства України, скасування рішень про оформлення набуття громадянства України, а також процедур подання цих документів та провадження за ними, виконання прийнятих рішень з питань громадянства України.

Дія Закону України «Про свободу пересування та вільний вибір місця проживання в Україні" [14] від 11.12.2003 року поширюється на всі категорії фізичних осіб, які на законних підставах перебувають на території України. У законі чітко зазначені підстави, що визначаються законними 
для перебування на території України, умови реєстрації місця проживання, місця перебування, зняття з реєстрації місця проживання.

Закон закріплює підстави (щодо території та щодо окремих категорій осіб), що обмежують свободу пересування. Прийняття цього Закону є вчасним і важливим у вирішенні міграційних питань в Україні.

Наступним фундаментальним законом у сфеpi міграції $є$ Закон України «Про правовий статус іноземців та осіб без громадянства» від 22.09.2011 року. Він визначає правовий статус іноземних громадян та осіб без громадянства в Україні, закріплює основні права, свободи та обов' язки іноземних громадян та осіб без громадянства, які проживають чи тимчасово перебувають в Україні, а також порядок вирішення питань, пов'язаних з їхнім в’їздом в Україну чи виїздом з України.

Особливе значення для здійснення ефективної міграційної політики має Закон України «Про біженців та осіб, які потребують додаткового або тимчасового захисту в Україні» від 08.07.2011 року [15].

Під час розробки Закону України «Про біженців та осіб, які потребують додаткового або тимчасового захисту» враховано положення Конвенції про статус біженців 1951 р. та Протоколу щодо статусу біженців 1967 р., резолюцій та рекомендацій ЄС щодо вдосконалення законодавства стосовно осіб, які $є$ шукачами притулку та потребують захисту.

Законом уперше введено допоміжні інститути захисту: додатковий та тимчасовий і створені умови надання захисту іноземцям та особам без громадянства, на яких не поширювались критерії визначення терміна «біженець», але стосовно яких існували обставини неможливості видворення за межі України.

Разом із цим з метою гармонізації національного законодавства до стандартів СС Законом України від 13.05.2014 № 1251-VII внесені зміни до статті 1 Закону і визначення поняття «додатковий захист» почало повністю відповідати Директиві Європарламенту і Ради ЄС 2011/95 стосовно стандартів для кваліфікації громадян третіх країн чи осіб без громадянства як бенефіціарів міжнародного захисту і стосовно єдиного статусу для біженців або для осіб, що мають право на додатковий захист, і стосовно змісту захисту, що надається.

Отже, відтепер відповідно до підпункту 13 пункту 1 ст. 1 Закону особа, яка потребує додаткового захисту, - особа, яка не є біженцем відповідно до Конвенції про статус біженців 1951 р. і Протоколу щодо статусу біженців $1967 \mathrm{p}$. та цього Закону, але потребує захисту, оскільки така особа змушена була прибути в Україну або залишитися в Україні внаслідок загрози їі життю, безпеці чи свободі в країні походження через побоювання застосування щодо неї смертної кари або виконання вироку про смертну кару чи тортур, нелюдського або такого, що принижує гідність, поводження чи покарання або загальнопоширеного насильства в ситуаціях міжнародного або внутрішнього збройного конфлікту чи систематичного порушення прав людини і не може чи не бажає повернутися до такої країни внаслідок зазначених побоювань.

Таким чином, можна стверджувати, що натепер в Україні є системна нормативно-правова база, яка дає передумови для сталого розвитку національної системи притулку. Водночас Україна готова до наступного етапу формування законодавства України про біженців, особливо в частині приділення уваги щодо інтеграції шукачів притулку та осіб, які отримали захист в Україні.

Також слід відзначити, що законодавство України взагалі не містить терміна політичний притулок, натомість Конституція України у ст. 26 встановила, що іноземцям та особам без громадянства може бути надано притулок у порядку, встановленому законом. Однак такого загального закону про притулок Україна поки ще не має.

Наступний не менш важливий та складний період для ефективного здійснення реалізації міграційної політики України - період гібридної війни Росії проти України. Процес законотворчості у міграційній сфері значно уповільнився після 2013 року через низку вагомих подій, таких як Революція Гідності, окупація АР Крим Російською Федерацією та проведення антитерористичної операції (АТО) у Донецькій та Луганській областях.

Протягом останніх 4 років в Україні відбувається становлення законодавства у сфері прав внутрішньо переміщених осіб (далі - ВПО). Восени 2014 р. парламентом було прийнято Закон України «Про забезпечення прав і свобод внутрішньо переміщених осіб» [16].

Необхідність прийняття цього Закону пояснювалася нагальною потребою щодо забезпечення реалізації гарантованих Конституцією України прав і свобод внутрішньо переміщених осіб, забезпечення тимчасовим житлом, сприяння в працевлаштуванні, продовженні здобуття освіти.

Згідно зі ст. 1 Закону України від 20.10.2014 p. № 1706-VII «Про забезпечення прав і свобод внутрішньо переміщених осіб» (далі - Закон № 1706), внутрішньо переміщеною особою є громадянин України, іноземець або особа без громадянства, яка перебуває на території України на законних підставах та має право на постійне проживання в Україні, яку змусили залишити або покинути своє місце проживання, зокрема, у результаті або з метою уникнення негативних наслідків збройного конфлікту.

Зі змісту Закону № 1706 випливає, що лише взята на облік внутрішньо переміщена особа може реалізувати свої передбачені законодавством України права й свободи. До речі, назва ст. 7 Закону № 1706 так і звучить: «Забезпечення реалізації 
прав зареєстрованих внутрішньо переміщених осіб на зайнятість, пенсійне забезпечення, загальнообов'язкове державне соціальне страхування, соціальні послуги, освіту» .

Відповідно до вимог ст. 4-1 Закону № 1706 з метою обліку внутрішньо переміщених осіб створюється Єдина інформаційна база даних про внутрішньо переміщених осіб. Згідно з ч. 9 ст. 4 цього Закону, порядок збирання та оброблення даних внутрішньо переміщеної особи затверджується Кабінетом Міністрів України. 3 цією метою 22.09.2016 р. Урядом було затверджено Порядок створення, ведення та доступу до відомостей Єдиної інформаційної бази даних про внутрішньо переміщених осіб.

18 січня 2018 року в Україні де-юре завершилася антитерористична операція (АТО) на Донбаci, ухваленням Закону про реінтеграцію Донбасу (повна назва - «Про особливості державної політики щодо забезпечення державного суверенітету України на тимчасово окупованих територіях у Донецькій і Луганській областях») Київ поставив крапку в дискусії про статус окремих районів Луганської та Донецької областей (ОРДЛО), а також про роль Росії в конфлікті на Сході України [17].

Що ж до останнього періоду в контексті вступу України до ЄС можна сказати, що він являє собою період нових міграційних викликів. Як уже зазначалося раніше, реформування міграційної сфери помітно активізувалося лише після того, як на саміті Україна - ЄС у листопаді 2010 р. Україні було надано План дій з лібералізації візового режиму [18].

На нашу думку, виконання Плану дій з лібералізації візового режиму тісно пов'язане із прийняттям у жовтні 2012 року Закону України «Про Єдиний державний демографічний реєстр та документи, що підтверджують громадянство України, посвідчують особу чи її спеціальний статус», який передбачає введення для українців так званих «біометричних паспортів», що є обов'язковою умовою безвізового в’їзду на територію Свросоюзу. Також варто зазначити, що регулюванню міграції у Плані присвячено багато й інших позицій [19].

На удосконалення міграційної політики України було спрямовано й завдання Плану дій з лібералізації візового режиму щодо запровадження моніторингу міграційних потоків як легальних, так і нелегальних, який має забезпечити надійну інформацію про стан речей, необхідну для прийняття управлінських рішень, яка має постійно оновлюватись [20].

Важливим кроком до сприяння реінтеграції трудових мігрантів, які повертаються, стало розроблення на виконання Закону «Про зайнятість населення» від 05 липня 2012 року [21] механізму визнання кваліфікації, набутої під час роботи. Важливо, що документ розроблявся на тристоронній основі за участю профспілок та працедавців. Сам факт появи відповідного механізму є однознач- но позитивним. Однак його практична цінність обмежена, оскільки підтвердження кваліфікації можливе лише за трьома робітничими професіями.

У квітні 2017 р. розпорядженням Уряду було затверджено План заходів щодо забезпечення реінтеграції в суспільство трудових мігрантів і членів їхніх сімей, розроблений на виконання Закону. Він, на жаль, не додав конкретності декларованим нормам, оскільки здебільшого містив положення на кшталт сприяти працевлаштуванню поверненців, вивчати зарубіжний досвід, проводити консультації тощо.

18 жовтня 2017 року Кабінетом Міністрів України затверджено Постанову № 784 (далі Постанова) «Про затвердження Порядку ведення Єдиного державного демографічного реєстру та надання з нього інформації, взаємодії між уповноваженими суб'єктами, а також здійснення ідентифікації та верифікації».

Порядок визначає механізм формування та ведення Єдиного державного демографічного реєстру (далі - Реєстр), надання інформації з Реєстру, видачі довідки про внесення інформації до Реєстру та про видані документи, що підтверджують громадянство України, посвідчують особу чи iї спеціальний статус, взаємодії між уповноваженими суб'єктами, а також процедуру здійснення ідентифікації та верифікації осіб [22].

У липні 2017 р. Уряд України ухвалив Стратегію державної міграційної політики на період до 2025 р. Це сталося через місяць після того, як українці отримали можливість подорожувати територією ЄС без віз, що великою мірою було результатом визнання значних успіхів, досягнутих державою в розбудові системи управління міграціями [23].

Новий документ замінив Концепцію державної міграційної політики України 2011 р., яку серйозно критикували фахівці і яка не відповідала ситуації у світі та в Україні, що останніми роками кардинально змінилася. Значне сприяння розробленню Стратегії надали Міжнародна організація 3 міграції, Європейський Союз, консультуючи щодо адаптації найкращих міжнародних практик до українського контексту.

Згідно з проведеним аналізом можна сказати, що відбувся справжній прорив в удосконаленні міграційного законодавства України, активізації міжнародного співробітництва. Виконання Плану дій з лібералізації візового режиму було вагомим чинником удосконалення міграційної політики України. У процесі його реалізації доопрацьовано чинне законодавство та ухвалено нове, врегульовано правовідносини, які раніше спеціальними законами не регулювалися, зокрема, у сфері зовнішньої трудової міграції та реінтеграції мігрантів, які повертаються.

Разом із тим не всі проблемні питання до кінця розв'язано, серйозної законотворчої роботи 
вимагає узгодження 3 міграційним законодавством законів, які регулюють інші сфери суспільних відносин, а також розроблення підзаконних нормативно-правових актів, що мають забезпечити механізми реалізації задекларованих норм.

\section{Iimepamypa}

1. Закон України «Про національні меншини в Україні». Закони, постанови та інші акти, прийняті Верховною Радою України на п'ятій сесії, січень-липень 1992 р. Ч. II. С. 306-309.

2. Положення про Комісію при Президентові України з питань громадянства : затверджене Указом Президента України від 27 березня 2001 р. № 215 (у редакції Указу Президента України від 27 червня 2006 р. № 588/2006). Офіи. вісник України. 2006. № 26. Ст. 1875.

3. Про біженців : Закон України від 24.12.1993 р. Відомості Верховної Ради України. 1994. № 16. Ст. 90.

4. Закон України «Про правовий статус іноземців». Закони, постанови та інші акти, прийняті Верховною Радою України на дев'ятій сесії, січень-лютий 1994 р. Ч. I. C. 289-300.

5. Конституція України. Прийнята на п'ятій сесії Верховної Ради України 28 червня 1996 року. Київ : Юрінком, 1996. 80 с.

6. Про затвердження положення про посвідчення біженця : Постанова КМУ від 14 березня 2012 р. № 202. URL: https://zakon.rada.gov.ua/laws/show/202-2012$\% \mathrm{D} 0 \% \mathrm{BF}$.

7. Про затвердження порядку надання біженцям грошової допомоги до пенсії : Постанова КМУ від 06.07.1998 № 1016. URL: https://zakon.rada.gov.ua/ laws/show/1016-98-\% D0\% BF.

8. Наказ Міністерства праці України «Про внесення змін та доповнень до Тимчасових положень про умови і порядок оформлення іноземним громадянам дозволів на працевлаштування в Україні», № 42 від 22 травня 1997 року. Офіиійний вісник України, 1997, число 26. С. 64-65.

9. Науково-практичний коментар до Закону України «Про імміграцію». Київ : «МП Леся», 2003. 208 с.

10. Про затвердження Порядку формування квоти імміграції, Порядку провадження за заявами про надання послуг на імміграцію і поданнями про його скасування та виконання прийнятих рішень, Порядку оформлення і видачі посвідки на постійне місце проживання : Постанова Кабінету Міністрів України 26 грудня 2002 року № 1983. Офіиійний вісник України. 2002. № 52. Ст. 2400.

11. «Про громадянство України»: Закон України від 18 січня 2001 р. № 2235-III. URL: https:// zakon.rada.gov.ua/laws/show/2235-14.

12. Положення про Комісію при Президентові України з питань громадянства : затв. Указом Президента України від 27 березня 2001 р. № 215 (у ред. Указу Президента України від 27 червня 2006 р. № 588/2006). Офіи. вісник України. 2006. № 26. Ст. 1875.

13. Порядок провадження за заявами і поданнями 3 питань громадянства України та виконання прийнятих рішень: затв. Указом Президента України від 27 березня 2001 р. № 215 (у ред. Указу Президента України від 27 червня 2006 р. № 588/2006). Офіu. вісник України. 2006. № 26. Ст. 1875.

14. Про свободу пересування та вільний вибір місця проживання в Україні : Закон України від 11.12.2003№1382-IV.URL:https://zakon2.rada.gov.ua/ laws/show/1382-15.
15. Про біженців та осіб, які потребують додаткового або тимчасового захисту у Україні : Закон України від 08.07.2011№3671-VI. URL: https://zakon.rada.gov.ua/ laws/show/3671-17.

16. Про забезпечення прав і свобод внутрішньо переміщених осіб : Закон України від 20.10.2014 p. № 1706-VII. URL: http://zakon2.rada.gov.ua/laws/ show/1706-18.

17. Про затвердження Порядку створення, ведення та доступу до відомостей Єдиної інформаційної бази даних про внутрішньо переміщених осіб : Постанова Кабінету Міністрів України від 22.09.2016 р. № 646 . URL: http://zakon2.rada.gov.ua/laws/show/646-2016$\%$ D0 $\%$ BF.

18. Про особливості державної політики щодо забезпечення державного суверенітету України на тимчасово окупованих територіях у Донецькій і Луганській областях : Закон України від 18.01.2018 № 2268-VIII. / Верховна Рада України: офіційний вебпортал. URL: https://zakon.rada.gov.ua/laws/show/2268-19.

19. Безвізовий діалог між Україною та ЄC. План дій 3 лібералізації візового режиму. URL: http://www.kmu.gov.ua/document/244813925/ План $\% 20$ д й $\% 20$ щодо\% 20 л берал зац $\% 20$ _С \% 20в_зового \% 20режиму\% 20для\% 20Ў кра_ни.pdf.

20. Малиновська О. Міграційна політика в Україні: формування, зміст, відповідність сучасним вимогам. Аналітична записка M1/2014. URL: http://www.ier.com.ua/files/publications/Policy Briefing Series/PB 01 migration 2013 ukr.pdf.

21. Про зайнятість населення : Закон України від 05 липня 2012 року № 5067-VI. URL: https:// zakon.rada.gov.ua/laws/show/5067-17.

22. Розпорядження Кабінету Міністрів України «План заходів щодо забезпечення реінтеграції в суспільство трудових мігрантів і членів їхніх сімей» від 12 квітня 2017 р. № 257-p. URL: http:// zakon3.rada.gov.ua/laws/show/257-2017-\% D1\% 80.

23. Розпорядження Кабінету Міністрів України «Про схвалення Стратегії державної міграційної політики України на період до 2025 року» від 12 липня 2017 p. № 482-p. URL: http://zakon5.rada.gov.ua/laws/ show $/ 482-2017-\%$ D1 $\% 80$.

\section{Анотація}

Дракохруст Т. В. Особливості правового забезпечення державної міграційної політики України. Стаття.

У статті проводиться досить Ірунтовний аналіз правового забезпечення державної міграційної політики України в контексті поетапного розвитку міграційного законодавства України, який має бути спрямований на досягнення трьох головних цілей: управління міграційними процесами (обсягом та спрямованістю міграційних потоків) в Україні, у тому числі регулювання в’їзду та виїзду мігрантів, шляхом здійснення імміграційного контролю; внутрішньої адаптації та інтеграції іммігрантів на території України; моніторинг та попередження виникнення міграційних викликів та загроз у контексті розвитку глобалізаційних процесів у світі. Автор виділяе та характеризуе конкретні етапи формування й становлення внутрішнього міграційного законодавства, а саме: до прийняття Конституції; після прийняття конституції, що включає період подальшої розробки, вдосконалення, систематизації та можливої кодифікації міграційного законодавства; у період гібридної війни Росії проти України; у контексті вступу України до ЄС. Акцентовано увагу на не менш важливому та складному періоді для ефективного здійснення 
реалізації міграційної політики України - періоді гібридної війни Росії проти України. Автор дійшов висновку, що відбувся справжній прорив в удосконаленні міграційного законодавства України, активізації міжнародного співробітництва. Виконання Плану дій з лібералізації візового режиму було вагомим чинником удосконалення міграційної політики України. Проте не всі проблемні питання до кінця розв'язано, серйозної законотворчої роботи вимагає узгодження з міграційним законодавством законів, які регулюють інші сфери суспільних відносин, а також розроблення підзаконних нормативно-правових актів, що мають забезпечити механізми реалізації задекларованих норм.

Ключові слова: міграційна політика, правове забезпечення, міграційне законодавство, нормативноправовий акт, міграційні виклики.

\section{Summary}

Drakokhrust T. V. Features of Legal Support of the State Migration Policy of Ukraine. - Article.

The article provides a sufficiently thorough analysis of the legal framework of the state migration policy of Ukraine in the context of the phased development of the migration legislation of Ukraine, which should be directed towards the achievement of three main objectives: management of migration processes (volume and direction of migration flows) in Ukraine, including regulation of entry and the departure of migrants through the implementation of immigration control; internal adaptation and integration of immigrants on the territory of Ukraine; monitoring and preventing the emergence of migration challenges and threats in the context of the development of globalization processes in the world. The author highlights and describes the concrete stages of formation and formation of internal migration legislation, namely: before the adoption of the Constitution; after the adoption of the Constitution, which includes the period of further development, improvement, systematization and possible codification of migration legislation; during the hybrid war against Russia; in the context of Ukraine's accession to the EU. Attention is paid to an equally important and difficult period for the effective implementation of Ukraine's migration policy - the period of Russia's hybrid war against Ukraine. The author came to the conclusion that there was a real breakthrough in improving the migration legislation of Ukraine, the intensification of international cooperation. The implementation of the Action Plan on Visa Liberalization was a significant factor in improving the migration policy of Ukraine. However, not all problematic issues are finally resolved, serious legislative work requires the alignment with migration law of laws that regulate other areas of public relations, as well as the development of subordinate legal acts that should provide mechanisms for the implementation of the declared norms.

Key words: migration policy, legal support, migration legislation, normative-legal act, migration challenges. 